\title{
THE RELATIONS BETWEEN ENTREPRENEURIAL ORIENTATION, ORGANIZATIONAL LEARNING AND ORGANIZATIONAL PERFORMANCE OF SMALL ENTERPRISES
}

\begin{abstract}
The study analyses the Organizational Performance antecedents, mainly the mediating role of the Entrepreneurial Orientation in the relationship between the Organizational Learning and the Organizational Performance in small Brazilian enterprises. A confirmatory factorial analysis was performed, through a structural equation modeling (SEM), to test the association between constructs. The results confirmed the hypothesis. The Entrepreneurial Orientation mediation role for the relationship between the Organizational Learning and the Organizational Performance. It was noted, however, that the organizational learning still needs to be better structured regarding formal procedures in those small enterprises researched.
\end{abstract}

KEYWORDS: Entrepreneurial Orientation, Organizational Learning, Organizational Performance, Small Enterprises, Brazil.

Vanessa Nunes de Souza Alencar Vasconcelos ${ }^{1}$ Amélia Silveira ${ }^{2}$ Flávio Santino Bizarrias ${ }^{3}$

\footnotetext{
${ }^{1}$ Professora pela Universidade Estadual do Piauí - UESPI, Piauí (Brasil).

Mestrado em Administração de Empresas pela Universidade de Fortaleza - UNIFOR, Ceará (Brasil). E-mail: vanessalencar@hotmail.com

${ }^{2}$ Doutora em Ciências da Comunicação pela Universidade de São Paulo - USP, São Paulo (Brasil). Professora pela Universidade do Oeste de Santa Catarina - UNOESC, Santa Catarina (Brasil). E-mail: ameliasilveira@gmail.com
}

${ }^{3}$ Mestre em Administração pela Universidade Nove de Julho - UNINOVE, São Paulo (Brasil). E-mail: flavioxsp@hotmail.com 


\section{INTRODUCTION}

Companies need to constantly adapt their organizational strategies to promote growth and organizational sustainability, as well as to develop competitive advantages. Therefore, the entrepreneurship arises as a viable option for enterprises to achieve the targeted results: sources of sustainable competitive advantage (Dess, Lumpkin \& Covin, 1997).

At first, research on entrepreneurship sought to understand the figure and characteristics of the entrepreneur's profile, and the economic and social environment that favored the emergence of entrepreneurship. From the 1980s, the studies about entrepreneurship change the focus to the entrepreneurial process and after, to the entrepreneurial orientation. (Castanhar, Dias \& Hope, 2006). According to Lumpkin and Dess (1996), the entrepreneurial orientation (EO) represents the decision-making practices and processes used to act in an entrepreneurial way. The study conducted by Miller (1983) points out this evolution: it changed the focus of analysis from the individual level to the organizational level.

Based on the works of Miller (1983) and of Lumpkin and Dess (1996) it can be understood that the EO represents the decision-making practices and processes used to act in an entrepreneurial way at the organizational level. Moreover, they postulate that five dimensions reflect the EO in organizations: innovativeness, proactivity, risk-taking, autonomy and competitive aggressiveness. (Miller, 1983; Lumpkin \& Dress, 1996). While Miller (1983) proposed the EO's one-dimensionality (innovativeness, risk-taking and proactivity), Lumpkin and Dess (1996) proposed that the EO is a multidimensional construct that can be manifested in the organization depending on the context and situation (autonomy and competitive aggressiveness). According to the authors, the five dimensions of EO may occur at different times, depending on environmental contingencies. Therefore, faced with different types of opportunities and challenges, the dimensions may or may not manifest. An organization can be considered entrepreneurial when some, and not necessarily all, dimensions of entrepreneurial orientation are developed.

Mainly from this study of Miller (1983), emerged some studies about entrepreneurial orientation, introducing gradually, a cumulative body of knowledge under development. Also, some research on entrepreneurial orientation turn, more specifically, to the relationship among constructs, these being: organizational performance, organizational learning, market orientation, innovation, among others, as well as to the variables that shape these relations.

These studies suggest that there is a positive relationship between the highest EO of an organization and its best organizational performance (OP), in other words, organizations with 
a greater entrepreneurial guidance is likely to achieve a greater business performance and consequently, success.

Rauch, Wiklund \& Lumpkin (2009) conducted a meta-analysis to explore the magnitude of the relationship between entrepreneurial orientation and organizational performance, and evaluate potential moderators that affect this relationship. The results indicated that the correlation of EO with OP is moderately large. The findings of the study reinforce that the dimensions of the EO (innovativeness, proactivity and risk-taking) impact in a balanced way on business performance.

The studies of Fernandes and Santos (2008); Wang (2008); Short, Payne, Brigham, Lumpkin and Brogberg (2009); Wiklund, Patzelt and Shepherd (2009); Frese (2009); Rhee, Park and Lee (2010); Covin and Lumpkin (2011); Wales, Monsen and McKelvie (2011); Zhao et al (2011);. Huang and Wang (2011), Alegre and Chiva (2013), Carneiro (2013); Reis Neto et al (2013); and Real, Roldán and Leal (2014) similarly approach this matter.

Thus, the objective of this work seeks to analyze the background of the Organizational Performance, particularly the mediator role of the Entrepreneurial Orientation in the relation among Organizational Learning and Organizational Performance in small Brazilian enterprises.

Based on the literature of the topic, the first research hypothesis was formulated, taking in consideration the definition of entrepreneurial orientation proposed by Miller (1983) comprised of the dimensions innovativeness, proactivity and risk taking.

H1: The entrepreneurial orientation of the organization is positively related to the organizational performance;

On the other hand, the organizational learning is essential for the survival in a competitive and dynamic environment (Garvin, 1993). An organization is considered steered to learning when a continuous improvement process is adopted, by encouraging learning and development for the transformation of structures, attitudes, behaviors Garver, (1993).

Slater and Narver (1995) define organizational learning as a knowledge development process that impacts the behavior of a company, especially in relation to organizational performance. For Barney (1991) the knowledge shaped in organizations is an important resource, because it is responsible for generating and sustaining the sources of competitive advantage in companies. For Hanssen-Bauer and Snow (1996) establishing a learning process comprises the fulfillment of some steps: information acquisition, interpretation, focused experimentation, dissemination of experience and knowledge restructuring. 
Fernandes and Santos (2008) and Li, Huang and Tsai (2009), among others, addressed the relationship between entrepreneurial orientation and organizational learning. The results show that EO is a key factor for learning, innovation and organizational performance. Rhee, Park and Lee (2010) from a theoretical review about EO, MO and learning orientation, have built a theoretical model and created hypothesis. These hypotheses were tested through the structural equation model, and the results confirm that the continued commitment of companies with learning is essential to innovation and performance in small technology-based companies. And that this relationship is fostered by the EO and the MO. This study provided a better understanding of performance promoters in small enterprises and also contributes with research regarding innovation and EO.

Based on this reasoning, it was developed the following hypothesis:

$\mathrm{H} 2$ : The organizational learning is positively related to the entrepreneurial orientation;

To the extent that the organizational learning constitutes a cumulative set of knowledge over time, its connection to the organizational performance depends on the establishment of processes that lead to this higher knowledge. However, in small enterprises with up to 49 employees, there might not have structured processes of organizational learning. This leads to the third and fourth hypotheses of this study.

H3: The organizational learning will have a negative and significant relationship with the organizational performance;

H4: The organizational learning will have a positive and significant relationship with the organizational performance through the mediation of entrepreneurial orientation, regardless of the moderation of the organization's life cycle.

These hypotheses are represented in Figure 1.

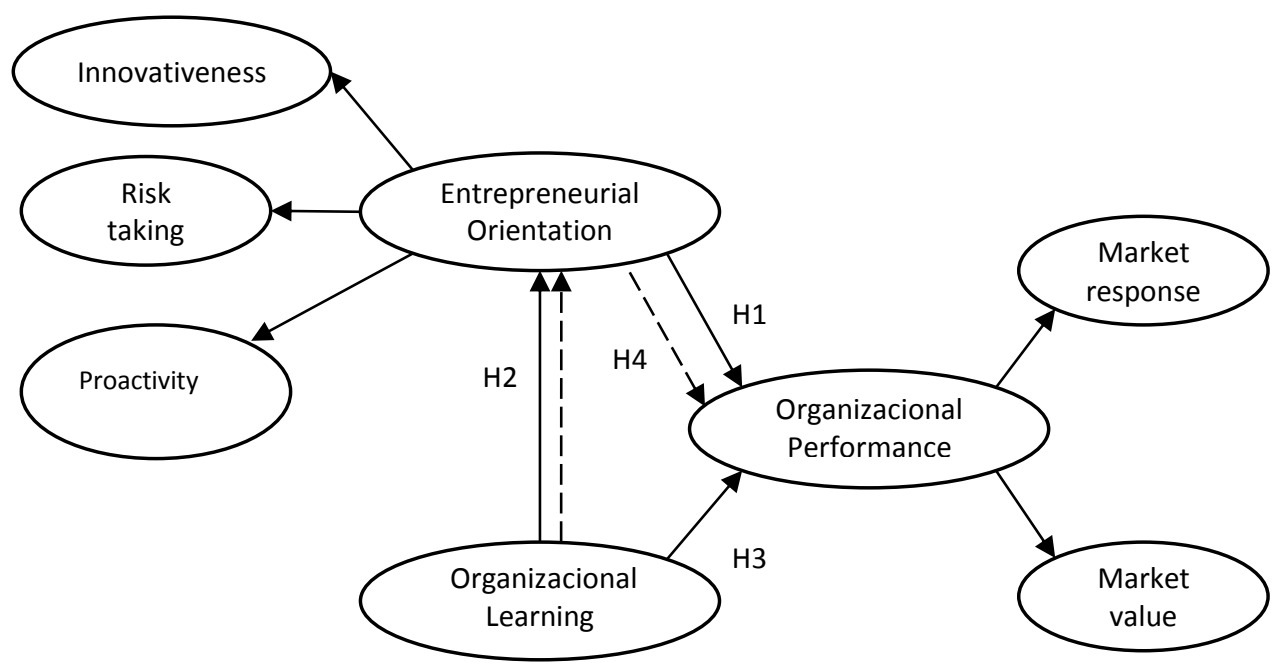

Figura 1 - Conceptual Model

*the dotted line represents the mediating relationship. 


\section{METHODS}

The research was a descriptive, quantitative, survey type. A stratified sample was defined from 200 managers of retail and service companies established in the Dirceu Arcoverde neighborhood in the city of Teresina, Piauí, Brazil. It was carried out between June and July of 2014. These individuals were included only once in the sample (Malhotra, 2012). The data collection instrument was a structured questionnaire with closed questions. It was divided into four parts, being them: the profile of the company, the entrepreneurial orientation, the organizational learning and the organizational performance.

The first part included questions that characterized the type of company (micro or small), the business activity sector (product or service) and the company's life cycle. The classification criteria for the type of company was proposed by the Brazilian Support Service for Micro and Small Enterprise (SEBRAE, 2014), where the micro company has up to 9 employees; and the small company has between 10 and 49 employees.

The company's life cycle was divided in companies with up to 4 years of establishment, and still being young; companies with 5 to 10 years of establishment, under development, and companies with more than 10 years of establishment, considered mature. In the second part, to measure the entrepreneurial orientation, it was adapted the scale developed by Carneiro (2014). In the third part the organizational learning was measured. In these two parts a Likert scale of 7 points of agreement was used ( 1 - totally disagree to 7 - totally agree). The fourth and last part measured subjectively the organizational performance.

These subjective measures involve comparative perceptions of the company's result in relation to its main competitor, where it was adapted the scale of Moore and Fairhurst (2003) and of González-Benito, González-Benito and Muñoz-Gallego’s (2008) scale. In this part was used a 7-points Likert scale (1 - much worse to 7 - much better).

Initially the data was explored using the software SPSS v.21 regarding the distribution normality through the Kolmogorov-Smirnov test, collinearity analysis through the Variance Inflation Factor test (VIF), where items with values below 5 could be kept, and the profile analysis of the companies surveyed. The small businesses were grouped into sub-samples by time of establishment, for further moderation test of this aspect, in the comparison of the proposed relationships in the conceptual model. For grouping the companies were taken in consideration the business cycle of the organizations.

The proposed relations of the conceptual model presented were analyzed through Structural Equation Modeling (SEM) using the software SmartPLS2.0M3 (Ringle, Wende, 
2010) which allows a better prediction of structural relations (Hair Jr., 2014) to observe the Determination Coefficient $\left(\mathrm{R}^{2}\right)$ of the dependent variable. It was considered acceptable $\mathrm{R}^{2}$ above $2 \%$ in social sciences. Discriminant and convergent analysis criteria were used to adjust the proposed model.

The convergent analysis was performed through the observation of factorial loads above 0.7 and the Average Variance Extracted (AVE) above 0.5. The discriminant validity was observed through the square root of the AVE of each variable versus its correlation with the other variables. Besides this, cross-loads were observed (crossloadings) of each item in its respective variable. In a complementary way the Cronbach's alpha and composed reliability were analyzed.

Are considered acceptable values those above 0.6 and 0.7 respectively. To accept the statistical significance of differences of the other tests were accepted values of $\alpha$ of $10 \%$, or $90 \%$ of reliability, with the value of t for student equal or above 1.67 , and p-value of 0.10 or less. This standard was used in the analysis of the structural relationships between variables through the resampling technique called Bootstrapping. It was also used this criteria in the mediation and moderation tests.

The mediation test was carried out using the Sobel test. For the moderation test the sample was separated according to the organization's time in business, and it was compared the statistical significance of the relationship between the dimensions of OL and EO as well as the relationship between the dimensions EO and OP.

\section{RESULTS}

This study included 200 companies, where 71 were considered young, 76 considered under development, and 53 considered mature. No question had missing data. The initial examination revealed no multicollinearity of the data. In all items the VIF stayed below 5 .

The data distribution was observed and the non-normal was identified ( $\mathrm{p}<0.001)$. The conceptual model was initially tested in an overall base with all organizations. In order to search for the convergent validity of the model, a total of seven items, with a factorial load below 0.7 were taken out.

Were eliminated 2 items of the dimension innovativeness, 4 items of the dimension Organizational Learning, and 1 item of the dimension Market Value.

The convergent validity adjust indicators can be seen in Table 1. 
Table 1 - Convergent validity

\begin{tabular}{|l|l|l|l|l|}
\hline Dimension & AVE & Composite Reliability & R Square & Cronbachs Alpha \\
\hline Organizacional learning & 0,563 & 0,865 & - & 0,806 \\
\hline Risk-taking & 0,556 & 0,787 & 0,538 & 0,594 \\
\hline Iinnovativeness & 0,679 & 0,863 & 0,654 & 0,763 \\
\hline Proactivity & 0,627 & 0,834 & 0,702 & 0,702 \\
\hline Market response & 0,663 & 0,853 & 0,822 & 0,740 \\
\hline Market value & 0,774 & 0,873 & 0,697 & 0,711 \\
\hline
\end{tabular}

Source: Research data.

The discriminant validity was also observed through the square root of AVEs of variables greater than its correlation with the other variables, as noted in Table 2 and confirmed by the cross-loads of items which were higher in their respective variables than in others (crossloadings), in Table 3.

Table 2 - Discriminant validity

\begin{tabular}{|l|l|l|l|l|l|l|}
\hline Dimensões & $\begin{array}{l}\text { Organizacional } \\
\text { learning }\end{array}$ & Risk-taking & Iinnovativeness & Proactivity & $\begin{array}{l}\text { Market } \\
\text { response }\end{array}$ & $\begin{array}{l}\text { Marke } \\
\text { t value }\end{array}$ \\
\hline $\begin{array}{l}\text { Organizacional } \\
\text { learning }\end{array}$ & $\mathbf{0 , 7 5 1 ^ { * }}$ & - & - & - & - & - \\
\hline Risk-taking & 0,406 & $\mathbf{0 , 7 4 6 *}$ & - & - & - & - \\
\hline Iinnovativeness & 0,549 & 0,376 & $\mathbf{0 , 8 2 4 *}$ & - & - & - \\
\hline Proactivity & 0,559 & 0,485 & 0,487 & $\mathbf{0 , 7 9 2 *}$ & - & - \\
\hline Market response & $-0,027$ & 0,033 & 0,133 & 0,110 & $\mathbf{0 , 8 1 5 *}$ & - \\
\hline Market value & 0,137 & 0,081 & 0,291 & 0,170 & 0,526 & $\mathbf{0 , 8 8 0 *}$ \\
\hline
\end{tabular}

Source: Research data, ${ }^{*}$ Square root of the AVE 
Table 3 - Crossloadings

\begin{tabular}{|r|l|l|l|l|l|l|}
\hline Item & $\begin{array}{l}\text { Organizacional } \\
\text { learning }\end{array}$ & Risk-taking & Iinnovativeness & Proactivity & $\begin{array}{l}\text { Market } \\
\text { response }\end{array}$ & $\begin{array}{l}\text { Market } \\
\text { value }\end{array}$ \\
\hline ao1 & $\underline{\mathbf{0 , 7 3 9}}$ & 0,318 & 0,409 & 0,455 & 0,049 & 0,109 \\
\hline ao2 & $\underline{\mathbf{0 , 7 7 9}}$ & 0,324 & 0,387 & 0,354 & $-0,075$ & 0,117 \\
\hline ao3 & $\underline{\mathbf{0 , 6 6 5}}$ & 0,208 & 0,362 & 0,311 & $-0,014$ & 0,044 \\
\hline ao4 & $\underline{\mathbf{0 , 7 5 4}}$ & 0,287 & 0,449 & 0,351 & 0,013 & 0,204 \\
\hline ao7 & $\underline{\mathbf{0 , 8 0 8}}$ & 0,361 & 0,444 & 0,574 & $-0,069$ & 0,045 \\
\hline inov1 & 0,450 & 0,183 & $\mathbf{0 , 7 6 2}$ & 0,368 & 0,147 & 0,237 \\
\hline inov2 & 0,432 & 0,347 & $\mathbf{0 , 8 5 2}$ & 0,370 & 0,132 & 0,239 \\
\hline inov3 & 0,476 & 0,379 & $\mathbf{0 , 8 5 5}$ & 0,461 & 0,060 & 0,246 \\
\hline proa1 & 0,490 & 0,403 & 0,395 & $\underline{\mathbf{0 , 7 8 0}}$ & $-0,027$ & 0,058 \\
\hline proa2 & 0,364 & 0,364 & 0,333 & $\underline{\mathbf{0 , 8 0 0}}$ & 0,063 & 0,083 \\
\hline proa3 & 0,469 & 0,384 & 0,426 & $\underline{\mathbf{0 , 7 9 6}}$ & 0,221 & 0,256 \\
\hline riscco3 & 0,290 & $\underline{\mathbf{0 , 6 2 6}}$ & 0,198 & 0,307 & $-0,046$ & 0,015 \\
\hline risco1 & 0,294 & $\underline{\mathbf{0 , 7 4 2}}$ & 0,283 & 0,334 & 0,121 & 0,086 \\
\hline risco2 & 0,327 & $\underline{\mathbf{0 , 8 5 2}}$ & 0,343 & 0,433 & $-0,006$ & 0,071 \\
\hline rm1 & $-0,042$ & 0,043 & 0,140 & 0,089 & $\underline{\mathbf{0 , 8 4 9}}$ & 0,448 \\
\hline rm2 & $-0,035$ & 0,021 & 0,143 & 0,092 & $\underline{\mathbf{0 , 8 9 3}}$ & 0,482 \\
\hline rm3 & 0,020 & 0,015 & 0,026 & 0,090 & $\underline{\mathbf{0 , 6 8 8}}$ & 0,343 \\
\hline vm1 & 0,178 & 0,080 & 0,304 & 0,204 & 0,377 & $\underline{\mathbf{0 , 8 5 9}}$ \\
\hline vm2 & 0,072 & 0,064 & 0,217 & 0,104 & 0,537 & $\mathbf{0 , 9 0 1}$ \\
\hline
\end{tabular}

Source: Research data

The structural relations of the conceptual model were proven to be adequate to explain $4.9 \%$ of the variance of the Organizational Performance, according to pre-established criteria (Hair et al, 2014), confirming hypotheses H1, H2 and H3. These indicators can be seen in Table 4. 
Table 4 - Structural relations

\begin{tabular}{|c|c|c|c|c|c|c|}
\hline Hypotheses & $\begin{array}{l}\text { Structural } \\
\text { relationship }\end{array}$ & Life Cycle & \begin{tabular}{|l|}
$\begin{array}{l}\text { Original } \\
\text { Sample }\end{array}$ \\
\end{tabular} & t Statistics & p-value & Status \\
\hline \multirow{4}{*}{ H1 } & \multirow{4}{*}{$\mathrm{EO}->\mathrm{OP}$} & General & 0,2824 & 2,3542 & 0,020 & confirmed \\
\hline & & Young & 0,287 & 1,703 & 0,093 & confirmed \\
\hline & & Under Devel & 0,302 & 1,797 & 0,076 & confirmed \\
\hline & & Mature & 0,326 & 1,709 & 0,093 & confirmed \\
\hline \multirow{4}{*}{$\mathrm{H} 2$} & \multirow{4}{*}{$\mathrm{OL}->\mathrm{EO}$} & General & 0,643 & 10,035 & 0,000 & confirmed \\
\hline & & Young & 0,722 & 6,194 & 0,000 & confirmed \\
\hline & & Under Devel & 0,769 & 7,922 & 0,000 & confirmed \\
\hline & & Mature & 0,489 & 3,385 & 0,001 & confirmed \\
\hline \multirow{4}{*}{ H3 } & \multirow{4}{*}{ OL- > OP } & General & $-0,131$ & 1,394 & 0,165 & confirmed \\
\hline & & Young & $-0,103$ & 0,822 & 0,414 & confirmed \\
\hline & & Under Devel & $-0,221$ & 1,351 & 0,181 & confirmed \\
\hline & & Mature & $-0,108$ & 0,853 & 0,397 & confirmed \\
\hline
\end{tabular}

Source: Research data

It was noted the mediation of EO to the relationship between OA and OP. The Sobel test was performed in the overall sample and in the subsamples of organizations classified by time of existence. These results are shown in Table 5. These results confirm the hypothesis H4.

Table 5 - Sobel test

\begin{tabular}{|l|l|l|}
\hline $\mathbf{O L} \rightarrow \mathbf{E O} \rightarrow \mathbf{O P}$ & Sobel test & p-value \\
\hline General sample $(\mathrm{n}=200)$ & 2,288 & 0,022 \\
\hline Young Enterprises $(\mathrm{n}=71)$ & 1,641 & $0,105^{*}$ \\
\hline Mature Enterprises $(\mathrm{n}=76)$ & 1,752 & 0,079 \\
\hline Ancient Enterprises $(\mathrm{n}=53)$ & 1,620 & $0,104^{*}$ \\
\hline
\end{tabular}

Source: Research data

*minimum difference to be considered in an exploratory research 
The moderation test considers the influence of the variable time of existence of the organization over the relationship between $\mathrm{OL}$ and $\mathrm{EO}$ and for the relationship between the EO and the OP. These relations confirm the mediation of EO. These results collaborate for the confirmation of the hypothesis H4. These results can be seen in Table 6 .

Table 6 - Time moderation of the mediation relation of the EO variable.

\begin{tabular}{|l|l|l|l|l|}
\cline { 2 - 5 } \multicolumn{1}{c|}{} & Relation & Young & Mature & Ancient \\
\hline \multirow{2}{*}{$\begin{array}{l}\text { General } \\
\text { sample }\end{array}$} & OL $\rightarrow$ EO & $\mathrm{t}=1,053 ; \mathrm{p}=0,294$ & $\mathrm{t}=1,053 ; \mathrm{p}=0,294$ & $\mathrm{t}=1,289 ; \mathrm{p}=0,199$ \\
\cline { 2 - 6 } & $\mathrm{EO} \rightarrow \mathrm{OP}$ & $\mathrm{t}=0,021 ; \mathrm{p}=0,983$ & $\mathrm{t}=0,088 ; \mathrm{p}=0,930$ & $\mathrm{t}=0,111 ; \mathrm{p}=0,912$ \\
\hline \multirow{3}{*}{ Young } & OL $\rightarrow$ EO & - & $\mathrm{t}=0,308 ; \mathrm{p}=0,758$ & $\mathrm{t}=1,474 ; \mathrm{p}=0,142$ \\
\cline { 2 - 6 } & $\mathrm{EO} \rightarrow \mathrm{OP}$ & - & $\mathrm{t}=0,062 ; \mathrm{p}=0,951$ & $\mathrm{t}=0,093 ; \mathrm{p}=0,926$ \\
\hline \multirow{3}{*}{ Mature } & OL $\rightarrow$ EO & - & - & $* \mathrm{t}=1,927 ; * \mathrm{p}=0,055$ \\
\cline { 2 - 6 } & $\mathrm{EO} \rightarrow \mathrm{OP}$ & - & - & $\mathrm{t}=0,034 ; \mathrm{p}=0,973$ \\
\hline
\end{tabular}

Source: Research data.

*only significant case found

\section{CONCLUSION}

It was confirmed in this study that the Entrepreneurial Orientation has a very strong relationship with Organizational Performance, in small businesses in general $(\Gamma=0,282$; $\left.\mathrm{t}_{(199)}=2,354 ; \mathrm{p}=0,019\right)$, as well as those young $\left(\Gamma=0,287 ; \mathrm{t}_{(70)}=1,703 ; \mathrm{p}=0,093\right)$, or under development $\left(\Gamma=0,301 ; \mathrm{t}_{(75)}=1,796 ; \mathrm{p}=0,076\right)$ or those mature $\left(\Gamma=0,325 ; \mathrm{t}_{(52)}=1,7094 ; \mathrm{p}=0,093\right)$. In a scenario of increasing uncertainties this characteristic is strategy in a small business organization, and may become the difference between staying or not in the marketplace. The young business organizations versus under consolidation showed no significant differences in the Entrepreneurial Orientation Dimension $\left(\mathrm{MO}_{\mathrm{EO}}\right.$ young $=5,87, \mathrm{MO}_{\mathrm{EO}}$ under consolidation=5,89, $\mathrm{p}=0,383$ ).

This appears to indicate that during the initial years, the organizations maintain this philosophy of action, but eventually lose over time. Enterprises in process of consolidation have lower Entrepreneurial Orientation compared to Younger or more Mature enterprises (Mmature, $60, p=0,005$ e p=0,003, respectively). 
The most mature companies wind up being less innovative than younger or consolidation companies. $\left(\mathrm{M}_{\text {Innovative mature }}=5,61, \mathrm{M}_{\text {Innovative young }}=5,95, \mathrm{M}_{\text {Innovative underconsolidation }}=6,06, \mathrm{p}=0,028\right.$ e $\mathrm{p}=0,006$, respectively). However, the Organizational Learning obtained a non-significant relationship with the organizational performance, not only in the sample as a whole $(\Gamma=-0,131$; $\left.\mathbf{t}_{(199)}=1,393 ; p=0,164\right)$, but in all other classifications, such as in young business $(\Gamma=-0,103$; $\left.\mathrm{t}_{(70)}=0,822 ; \mathrm{p}=0,413\right)$, under consolidation $\left(\Gamma=-0,221 ; \mathrm{t}_{(75)}=1,350 ; \mathrm{p}=0,180\right)$ and matures $(\Gamma=$ 0,$\left.107 ; \mathrm{t}_{(53)}=-0,8534 ; \mathrm{p}=0,397\right)$.

These scenarios suggest that the Entrepreneurial Guidance could result in different results in the Organizational Performance regarding the companies' life cycle, however, this does not occur $\left(\mathrm{M}_{\mathrm{OP}}\right.$ mature $=5,078, \mathrm{M}_{\mathrm{OP}}$ young $=5,016 \mathrm{e} \mathrm{M}_{\mathrm{OP}}$ under consolidation $=5,087, \mathrm{p}>0,05$ for all combinations).

Another element must coexist in the development of small size business organizations that combined with the Entrepreneurial Orientation wind up balancing the result in the Organizational Performance, and mitigating the effect of the Entrepreneurial Orientation. This element could be the Organizational Learning, which also does not change in organizations, in accordance with the life cycle of the company ( $\mathrm{M}_{\mathrm{OL} \text { young }}=6,51, \mathrm{M}_{\mathrm{OL}}$ under consolidation $=6,45$ e $\mathrm{M}_{\mathrm{OL}}$ mature $=6,40, p$-value $>0,05$ in all possible combinations). It is then up to the Entrepreneurial Orientation the crucial role in influencing organizational results.

For small size businesses managers these results suggest that the Organizational Learning should be structured as a process that can generate an effective contribution for the expansion of the results of the company.

This learning process should also contribute to the innovative capacity of the organization, another aspect previously identified as of minor contribution for the organizations in this study.

\section{REFERENCES}

Alegre, J.; Chiva, R. (2013). Linking Entrepreneurial Orientation and Firm Performance: The Role of Organizational Learning Capability and Innovation Performance. Journal of Small Business Management, 51 (4): 491-507.

Barney, J. (1991). Firm Resources And Sustained Competitive Advantage. Journal of Management, 17 (1): 99-120. 
Baker, W. E.; Sinkula, J. M. (2009). The Complementary Effects of Market Orientation and Entrepreneurial Orientation on Profitability in Small Businesses. Journal of Small Business Management, 47 (4): 443-464.

Carneiro, K.D.A. (2013). Maturidade em Gerenciamento de Projetos e Orientação Empreendedora: Análise das Relações em Organizações de Software. Unpublished doctoral thesis, University of Nove de Julho, São Paulo, Brazil.

Castanhar, J. C.; Dias, J. F.; Esperança, J. P. (2006) Orientação Empreendedora, Reconhecimento de Oportunidades e Desempenho em Pequenas e Médias Empresas Brasileiras: Evidências de Dois Estudos de Caso. In: ENCONTRO NACIONAL DE PROGRAMAS DE PÓS-GRADUAÇÃO EM ADMINISTRAÇÃO, 30, 2006. Proceedings...Rio de Janeiro, Anpad.

Chin, W. W. (1998). The Partial Least Squares Approach For Structural Equation Modeling. In: Marcoulides, G.A. (Ed.). Modern Methods for Business Research. London: Lawrence Erlbaum Assoc. p. 295 - 236.

Cohen, J. (1988). Statistical Power Analysis for the Behavioral Sciences. $2^{\text {nd }}$. Ed. New York: Psychology Press.

Covin, J. G.; Lumpkin, G. T. (2011) Entrepreneurial Orientation Theory and Research: Reflections on a Needed Construct. Entrepreneurship Theory And Practice, 35(5): 855-872.

Covin, J. G.; Slevin, D. P. (1989). Management of Small Firms in Hostile and Benign Environments. Strategic Management Journal, 10(1):75-87.

Dess, G. G.; Lumpkin, G. T.; Covin, J. G. (1997). Entrepreneurial Strategy Making and Firm Performance: Tests of Contingency and Configurationally Models. Strategic Management Journal, 18 (9):677-695.

Fernandes, D. V. D. H.; Santos, C. P. (2008). Orientação Empreendedora: Um Estudo Sobre as Conseqüências do Empreendedorismo nas Organizações. RAE electron, São Paulo, 7(1): ???

Garver, J. A. (1993). "Success Story!": The Evolution Of Economic Development In Broward County, Florida. Economic Development Review,11(3):85-90.

Garvin, D. A. (1993). Building A Learning Organization. Harvard Business Review, 71(4): 78-91.

González-Benito, Ó.; González-Benito, J.; Muñoz-Gallego, P. A. (2009). Role Of Entrepreneurship And Market Orientation In Firms' Success. European Journal Of Marketing, 43(3/4): 500-522.

Hair, J. F. et al. (2014). A Primer on Partial Least Squares Structural Equation Modeling (Plssem). Los Angeles: Sage, 2014.

Hanssen-Bauer, J.; Snow, C. (1996). Responding to Hypercompetition: The Structure and Processes of a Regional Learning Network Organization. Organization Science, 7 (4): 413-28. 
Huang, S.K. ;Wang, Y.L. (2011). Entrepreneurial Orientation, Learning Orientation, and Innovation in Small and Medium Enterprises. Procedia Social and Behavioral Sciences, 24:563-570.

Malhotra, N. (2012). Pesquisa de Marketing: Uma Orientação Aplicada. 6. Ed. Porto Alegre: Bookman, 2012.

Moore, M.; Fairhurst, A. (2003). Marketing Capabilities and Firm Performance in Fashion Retailing. Journal Of Fashion Marketing And Management, 7 (4): 386-397.

Lee, S. M.; Lian, S.; Pathak, R. D. (2011).Culture and Entrepreneurial Orientation: A MultiCountry Study. International Entrepreneurship Management Journal, 7:1-15.

Li, Y.; Huang, J.; Tsai, M. (2009). Entrepreneurial Orientation and Firm Performance: The Role of Knowledge Creation Process. Industrial Marketing Management, 38(4):440-449.

Lumpkin, G. T.; Dess, G. G. (2001). Linking Two Dimensions of Entrepreneurial Orientation to Firm Performance: The Moderating Role of Environment and Industry Life Cycle. Journal Of Business Venturing, 16 (5): 429-451.

Lumpkin, G. T.; Dess, G. G. (1996). Clarifying the Entrepreneurial Orientation Constructand Linking It to Performance. Academy Of Management Review, 21(1):135-172.

Miller, D. (1983).The Correlates of Entrepreneurship In Three Types of Firms. Management Science, 29 (7):770-791.

Rauch, A. et al. (2009). Entrepreneurial Orientation and Business Performance: An Assessment of Past Research and Suggestions for the Future. Entrepreneurship Theory and Practice, 33: 761-787.

Real, J.C. ; Roldán, J.L;. Leal, A. (2014). From Entrepreneurial Orientation and Learning Orientation to Business Performance: a Analyzing the Mediating Role of Organizational Learning and Moderation Effects of Organizational Size. British Journal of Management, 25(186-208).

Reis Neto, J.F. dos, et al. (2013). As Conexões entre Orientação Empreendedora, Capacidade de Marketing e a Percepção do Desempenho Empresarial:Evidências Empíricas das Micro e Pequenas Empresas Varejistas. RAM, Rev.Adm. Mackenzie, São Paulo, 13(6):236271.

Rhee, J.; Park, T.; Lee, D. H. (2010). Drivers of Innovativeness and Performance for Innovative SMEs In South Korea: Mediation of Learning Orientation. Technovation, 30(1): 6575 .

Ringle, C.M.;Wende, S.; Will, A. (2005). SmartPLS 2.0 (beta). SmartPLS.

Slater, S. F.; Narver, J. C. (1995). Market Orientation And The Learning Organization. Journal of Marketing, 59(3): 63-74. 
SEBRAE/GO. Critérios e conceitos para classificação de empresas. Disponível em: http://arquivopdf.sebrae.com.br/uf/goias/indicadores-das-mpe/classificacao-empresarial Acesso em: 20 Jul. 2014.

Short, J. C. et al. (2009). Family Firms and Entrepreneurial Orientation in Publicly Traded Firms: A Comparative Analysis Of The S\&P 500. Family Business Review, 22 (1): 9-24.

Wales, W.; Monsen, E.; Mckelvie, A. (2011). The Organizational Perva-Siveness of Entrepreneurial Orientation. Entrepreneurship Theory and Practice, 35(5): 895-923.

Wang, C.L. (2008). Entrepreneurial Orientation, Learning Orientation, and Firm Performance. Entrepreneurship Theory and Practice, 32 (4):635-656.

Wiklund, J.; Patzelt, H.; Shepherd, D. A. (2009). Building an Integrative Model of Small Business Growth. Small Business Economics, 32(4): 351-374.

Zhao, Y. et al. (2011). Entrepreneurial Orientation, Organization Learning and Performance: Evidence from China. Entrepreneurship Theory and Practice, 35 (2):293-317. 